second-rank power) afford to wait that long? Another couple of decades, perhaps? Of course not. The effort in the schools to which the British Association would dedicate itself is essential, but is a long-term project. The immediate need is to find a way of helping researchers now in post to believe cheerfully in their work, even when the prospect that they will earn substantial royalty fees from industry is small. Maybe, the British prime minister's decision on the AIDS survey notwithstanding, the British Association will find an answer by next year.

\section{More funny money}

The only solution of Europe's money problem is to require European states to accept ECUs as legal tender.

Mr Nigel Lawson, the British chancellor of the exchequer, is in a curious dilemma. Last week, which he spent at Antibes in the company of other finance ministers of the 12 members of the European Community, he argued vigorously (as is his wont) against the notion that there should be a common European currency and a central bank to go wth it. But next weekend he will be in the United States, arguing that Britain should remain the second largest subscriber to the International Monetary Fund, which is a perfectly respectable international central bank. Why the contradiction?

The puzzle is most easily explained by supposing that what Lawson said last weekend at Antibes was a kind of joke. Faced with the job (for which he volunteered at Madrid in June) of devising alternatives to Europe's plan for a common currency, he appears to have offered the notion that all European currencies should be considered equal, coupled with the hope that some in due course would come to seem more equal than others. Lawson appears not to have committed his plan to paper, so that it is not certain what he meant. That may not matter much, given that critics of the plan (among whom Lawson may be included) are unlikely to give it an easy passage.

But there is a need for a European currency. Otherwise the banks will be the only winners from the single market. But at this late stage in history, it can make no sense to devise some non-monetary substitute for a currency germanium, or even palladium, would not suit. Notions that the commodity called energy would make the basis for the ideal unit of currency are of course mistaken; if currencies must be linked with commodities, the commodities must be otherwise useless, as gold used to be.

Nor can it make sense that there should be a kind of competition between national currencies, as Lawson proposes. the optimists may believe that good currencies will take precedence, but will it not still be advantageous to pay for good and services in the cheapest, not the most expensive currency, thus verifying Gresham's Law ... . The obvious solution is to have two legal currencies everywhere - the national currency and the European Currency Unit. Then you feel your way. NATURE · VOL 341 · 14 SEPTEMBER 1989

\section{End of apartheid?}

The South African election last week must be demonstrated to have been a hopeful sign or it will be the last.

White South Africa, which re-elected its Nationalist government last week with a reduced majority, has a nasty job to tackle next: it has to persuade its new government, elected on the basis of "moderate reform", that there is no such thing. Reform is either radical - of or pertaining to the root - or it is not reform. South Africa's immediate problem is that its new government, having survived an election marked by brutality against non-whites, unjustifiable even by the calculation that its performance would otherwise have been even worse, and the opposition more wedded to apartheid, may still be preoccupied with electoral arithmetic. The government must be made to understand that it is unique among elected governments in being the one whose success will hang on whether it can create the conditions in which there will be another election of any kind by which its successor can be legitimized.

The article on page 96 by Dr Stuart John Saunders, the vice-chancellor of the University of Cape Town, and his colleagues typifies the process of persuasion that must be begun. Neither readers of this journal nor the government of South Africa should be lulled into complacency by the simplicity of what they have to say. It will be noted, for example, that Saunders et al. use the word "postapartheid" often, especially towards the end of their article. What does that mean? Simply, it means that they believe there will be a time when apartheid has disappeared, and when the need to provide secondary schooling for those whom white South Africans now constitutionally set apart will be so great that even traditionally proud universities may have to reset their sights at more practical goals than those of excellence. The comfort, for Saunders and his colleagues and the rest of us, is that they are by no means alone.

Mr F.W. de Klerk, this week's new state president of South Africa, is strangely more isolated. His difficulty may no longer be electoral, but he has assiduously sought (and won) the sufferance of people outside South Africa (in Zambia as well as Western Europe) by his assurances that reform means the root-and-branch stuff. If his election last week had passed off peacefully, he might have had some time in which to demonstrate that he meant what he said. As things are, there is less time - indeed, there is very little. The release of Nelson Mandela is at the top of every reformer's list, but should be a formality. Abolishing the Group Areas Act, or something like it, by the end of the month would be more to the point. But the enduring need is to find the funds with which to educate all South Africans. If de Klerk does not hurry in that direction, others elsewhere should take on the burden. Whatever happens, people will be keeping a close eye on South Africa. 